Available online at: http://ejournal-balitbang.kkp.go.id/index.php/ifrj
e-mail:ifrj.puslitbangkan@ gmail.com
INDONESIANFISHERIES RESEARCHJOURNAL
Volume 27 Nomor 2 December 2021
p-ISSN: 0853-8980
e-ISSN: 2502-6569
Accreditation Number RISTEK-BRIN: 85/M/KPT/2020

\title{
THE ANNUAL CHANGES OF CPT OF TROLLING LINES FISHERY IN PALABUHANRATU WEST JAVA, INDONESIA
}

\author{
Eflysa Aprilia*, Herman Hamdani, Agus Asep Handaka and Alexander M.A Khan \\ ${ }^{1}$ Faculty of Fisheries and Marine Science, Universitas Padjadjaran, Bandung, Indonesia, \\ Jalan Raya Bandung-Sumedang Km 21 Jatinangor, Jawa Barat 45363 Indonesia \\ Received; February 14-2020 Received in revised from February 24-2021; Accepted April 28-2021
}

\begin{abstract}
Trolling line is one of the fishing gears that is categorized as line-fishing with rods. Troll line fishery in Palabuhanratu heavily depends on the installation of a deep-sea fish aggregating device (FADs). The deployment of FADs as a destined troll liner's fishing ground in southern Palabuhanratu, which is geographically located at coordinates between $7^{\circ}$ to $9^{\circ} \mathrm{S}$ and $104^{\circ}$ to $106^{\circ} \mathrm{E}$ in the Indian Ocean. The FADs' coordinates locations have been set in a portable handheld global position system (GPS) by fishers. This study provides new information on troll liner catch-per-trip (CPT) based on fishers' monthly data, ranging from 2005 to 2018 . The results showed that the highest catches occurred between September and October every year with the maximum catch rate was $1567.20 \mathrm{~kg} /$ trip in February 2006 while the lowest one was $174.10 \mathrm{~kg} /$ trip in August 2010. The average troll liner catches from 2005 to 2018 was $740.33 \mathrm{~kg} /$ trip. Based on monthly catch data from 2005 to 2018, the highest CPT occurred in 2016.
\end{abstract}

\section{Keywords: Catch-per-trip; Palabuhanratu; Trends; Trolling Lines}

\section{INTRODUCTION}

The total catches landed in the southern-off Indian Ocean of West Java fluctuated across the years (Nurhayati \& Purnomo, 2017). Palabuhanratu landing site is located at the Indonesian Fishery Management Area (FMA) 573, which extends outward in the Indian Ocean from the southern-off Java to Nusa Tenggara (Hartini et al., 2013). Skipjack tuna (Katsuwonus pelamis) is the dominant species caught by trolling lines, then followed by yellowfin tuna (Thunnus albacares), and other pelagic species, such as little eastern tuna (Euthynnus affinis) and swordfish (Xiphias gladius) (Food and Agriculture Organisation of the United Nations (FAO), 2001; Puspito, 2009). Most of the fishing gears used by fishers in Palabuhanratu are trolling lines, handline, and kite fishing (Inizianti, 2010). Trolling lines fishery strongly depends on the availability of baits during the fishing operation, as research by Khan et al. (2018) found that in eastern Indonesia, line fishing relies on the availability of baits (Khan et al., 2020). Types of bait mostly used by the fishers are both natural and artificial baits during the fishing operations (Food and Agriculture Organisation of the United Nations, 2001; Wijaya, 2012; Yahya \& Rahmat, 2017). Moreover, trolling lines in this area also use fish aggregating devices (FADs) for fishing operations.

Usually, the catch-per-trip (CPT) to be considered as an estimation of the fish that have been taken from wild stock. The catch-per-unit-effort is mostly useful if the relationship between catch and effort is linear through the origin (strict proportionality) (Garrod, 1964; Gulland, 1964; Lima et al., 2000; Ricker, 1975). Catchper-trip (CPT) are the results of assumptions that can be taken in different combinations: (i) fish vulnerability to fishing gears; (ii) the distribution of stock space that determines the distribution of fishing efforts (Paloheimo \& Dickie, 1964). Various vessel characteristics and fishers affect the quantity of fish taken by the boats per trip, and therefore, in the end, it will affect the accuracy of the trip as a fishing effort unit. These include the size of the vessels, storage capacity, crew skills, and the availability of technology (Food and Agriculture Organisation of the United Nations, 1980; Oxenford, 1999). This research aims to determine the dynamics of catch and effort from 2005 to 2018 as a baseline to describe the annual trend catch-per-trip (CPT) of trolling lines as a piece of underlying scientific evidence for fishing evaluation and management of trolling lines fishery in Palabuhanratu. 


\section{MATERIALS AND METHODS Research Site}

The research was conducted from March to October 2019 at Palabuhanratu, West Java, Indonesia. Fishing operation time normally occur $s$ from dawn (05:00 am) until dusk (06:00 pm), but sometimes until late evening when they are looking for other targeted species, such as squids. The fishing ground is where the FAD's deployed, with coordinates between $7^{\circ}$ to $9^{\circ} \mathrm{S}$ and $104^{\circ}$ to $106^{\circ} \mathrm{E}$. The FAD's sites have been stored by the fishers using handheld GPS. Every trolling line has their FAD sites and is only allowed for fishing at their own FADs' sites with fishing depth ranging from 20 to $60 \mathrm{~m}$ deep.

\section{Data Analysis}

Catch-per-trip data on this paper is defined as the volume of landings $(\mathrm{kg})$ divided by number of trips of trolling lines. More detail is as the following formula (Noija et al., 2014):

$$
\text { Catchpetrip }(C P T)=\frac{\operatorname{catch}(\mathrm{kg})}{\text { trip }}
$$

\section{RESULTS AND DISCUSSION \\ Result}

\section{Monthly Catch and Trip 2005-2018}

Based on the monthly catch-per-trip box plot in 2005 - 2018 (Figure 1.) shows that overall catch variability over 2005-2018 was low from November to March. While on the contrary, the trip data showed variability over 2005-2018 was high from June to September (Figure 2). The highest catch was 1567, 2 $\mathrm{kg} /$ trip in February 2006, while the lowest was 174.10 $\mathrm{kg} /$ trip in August 2010 (Table 1). Trip data showed that the lowest was 4 trips that occurred in October 2005 and 2006, while the highest was 333 trips in June 2011 (Table 2).

Table 1. Monthly catch $(\mathrm{kg})$ of trolling lines from 2005 to 2018

\begin{tabular}{ccccccccccccc}
\hline \multirow{2}{*}{ Year } & $\mathbf{J}$ & $\mathbf{F}$ & $\mathbf{M}$ & $\mathbf{A}$ & $\mathbf{M}$ & $\mathbf{J}$ & $\mathbf{J}$ & $\mathbf{A}$ & $\mathbf{S}$ & $\mathbf{O}$ & $\mathbf{N}$ & $\mathbf{D}$ \\
\hline $\mathbf{2 0 0 5}$ & 8787 & 25871 & 24206 & 20310 & 15562 & 24090 & 15985 & 19319 & 3328 & 3575 & 14951 & 22820 \\
$\mathbf{2 0 0 6}$ & 45186 & 57986 & 34950 & 57106 & 20642 & 14765 & 12570 & 22357 & 15164 & 1791 & 13134 & 13678 \\
$\mathbf{2 0 0 7}$ & 41229 & 19391 & 10161 & 35911 & 7112 & 21137 & 33627 & 30883 & 28035 & 5091 & 36719 & 14772 \\
$\mathbf{2 0 0 8}$ & 10663 & 6588 & 20131 & 25277 & 29536 & 46149 & 57624 & 26590 & 26794 & 27666 & 8729 & 6420 \\
$\mathbf{2 0 0 9}$ & 16377 & 19474 & 26634 & 51370 & 64042 & 79203 & 66325 & 81260 & 58119 & 66028 & 53596 & 18793 \\
$\mathbf{2 0 1 0}$ & 50440 & 78556 & 130043 & 91524 & 140061 & 118820 & 118851 & 28553 & 17323 & 46999 & 25273 & 41960 \\
$\mathbf{2 0 1 1}$ & 34954 & 57696 & 48933 & 81062 & 74581 & 73943 & 98087 & 105452 & 151690 & 155608 & 79854 & 61799 \\
$\mathbf{2 0 1 2}$ & 6106 & 16341 & 16388 & 31404 & 70089 & 156755 & 141287 & 124557 & 129786 & 93187 & 60587 & 28584 \\
$\mathbf{2 0 1 3}$ & 6764 & 12259 & 22522 & 54511 & 149157 & 163126 & 73110 & 93893 & 125523 & 114950 & 63861 & 25116 \\
$\mathbf{2 0 1 4}$ & 22324 & 22189 & 57412 & 75642 & 59254 & 59857 & 65380 & 35161 & 97059 & 41842 & 32517 & 48233 \\
$\mathbf{2 0 1 5}$ & 15854 & 15658 & 26505 & 66032 & 75870 & 53628 & 62749 & 72583 & 127237 & 60387 & 30715 & 19425 \\
$\mathbf{2 0 1 6}$ & 17609 & 12205 & 35134 & 41559 & 43625 & 37062 & 22969 & 21455 & 14889 & 21183 & 29839 & 30111 \\
$\mathbf{2 0 1 7}$ & 27312 & 29334 & 43502 & 60367 & 52983 & 52166 & 117353 & 98534 & 72480 & 58508 & 32633 & 16484 \\
$\mathbf{2 0 1 8}$ & 8602 & 25321 & 60854 & 45405 & 46017 & 43336 & 72220 & 65857 & 58417 & 83014 & 34740 & 31815 \\
\hline
\end{tabular}

Table 2. Monthly trolling lines trip from 2005 to 2018

\begin{tabular}{|c|c|c|c|c|c|c|c|c|c|c|c|c|}
\hline \multirow{2}{*}{ Tahun } & \multicolumn{12}{|c|}{ Month } \\
\hline & $\mathbf{J}$ & $F$ & M & A & M & $\mathbf{J}$ & $\mathbf{J}$ & A & $\mathrm{S}$ & 0 & $\mathbf{N}$ & D \\
\hline 2005 & 13 & 18 & 23 & 20 & 17 & 17 & 17 & 17 & 5 & 4 & 17 & 20 \\
\hline 2006 & 32 & 37 & 37 & 41 & 27 & 16 & 13 & 17 & 15 & 4 & 14 & 11 \\
\hline 2007 & 36 & 22 & 11 & 30 & 13 & 24 & 30 & 31 & 20 & 6 & 38 & 25 \\
\hline 2008 & 18 & 12 & 25 & 30 & 43 & 46 & 50 & 30 & 28 & 41 & 14 & 13 \\
\hline 2009 & 27 & 29 & 47 & 85 & 95 & 126 & 109 & 111 & 99 & 94 & 74 & 44 \\
\hline 2010 & 98 & 162 & 184 & 169 & 234 & 261 & 264 & 164 & 80 & 152 & 83 & 76 \\
\hline 2011 & 78 & 115 & 111 & 156 & 175 & 333 & 150 & 171 & 147 & 115 & 76 & 72 \\
\hline 2012 & 19 & 51 & 36 & 133 & 97 & 175 & 147 & 130 & 118 & 93 & 75 & 47 \\
\hline 2013 & 14 & 18 & 45 & 98 & 202 & 245 & 190 & 177 & 195 & 144 & 142 & 68 \\
\hline 2014 & 49 & 47 & 59 & 122 & 130 & 139 & 132 & 101 & 144 & 90 & 77 & 79 \\
\hline 2015 & 36 & 36 & 48 & 96 & 119 & 104 & 99 & 110 & 125 & 83 & 49 & 34 \\
\hline 2016 & 34 & 24 & 42 & 58 & 59 & 57 & 33 & 43 & 32 & 36 & 42 & 42 \\
\hline 2017 & 55 & 37 & 55 & 75 & 78 & 66 & 102 & 91 & 86 & 83 & 52 & 24 \\
\hline 2018 & 19 & 31 & 58 & 67 & 66 & 56 & 70 & 68 & 55 & 55 & 30 & 28 \\
\hline
\end{tabular}


Catches of trolling lines show fluctuations (Figure 1). The minimum catch ranged from $1,791 \mathrm{~kg}$ in October to $20,310 \mathrm{~kg}$ in April during 2005 - 2018, with the average catch ranging from $27,143 \mathrm{~kg}$ in December to $68,438 \mathrm{~kg}$ in July. The maximum value ranges from $50,440 \mathrm{~kg}$ in January to $163,126 \mathrm{~kg}$ in June. In general, the distribution of catch data is not symmetrical, which shows that the median value is not in the middle of the box, and the top whisker is high er than the bottom whisker. The graph also indicates there is no extreme value within the $2005-2018$ catch data.

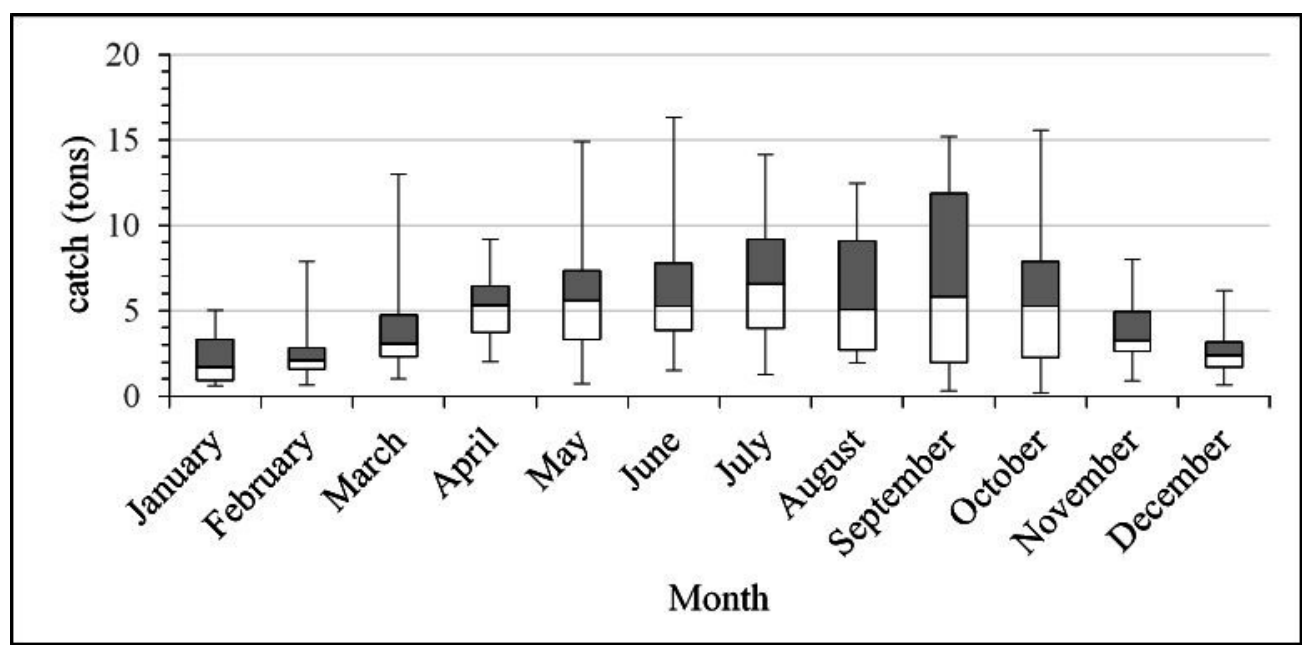

Figure 1. The summated monthly catch data (ton) showing the range of variability within each month over the years 2005-2018. The band inside each bar represents the median, and the middlebox represents the inter quartile range, while the lines outside the box ("whiskers") describe the lower and upper quartiles.

Trip data for trolling lines showed fluctuations in trends (Figure 2.). Minimum trip data ranged from four trips in October to 20 trips in April. The average monthly for the $2005-2018$ trip data ranged from 37.7 trips in January to 118.9 trips in June. The maximum monthly trip ranged from 79 trips in December (2018) to 333

trips in June (2011). In general, the distribution of catch data is not symmetrical, as the median is not in the middle of the box, and the top whisker is longer than the bottom whisker. Based on the picture also shows that there is no extreme value in the capture data trip.

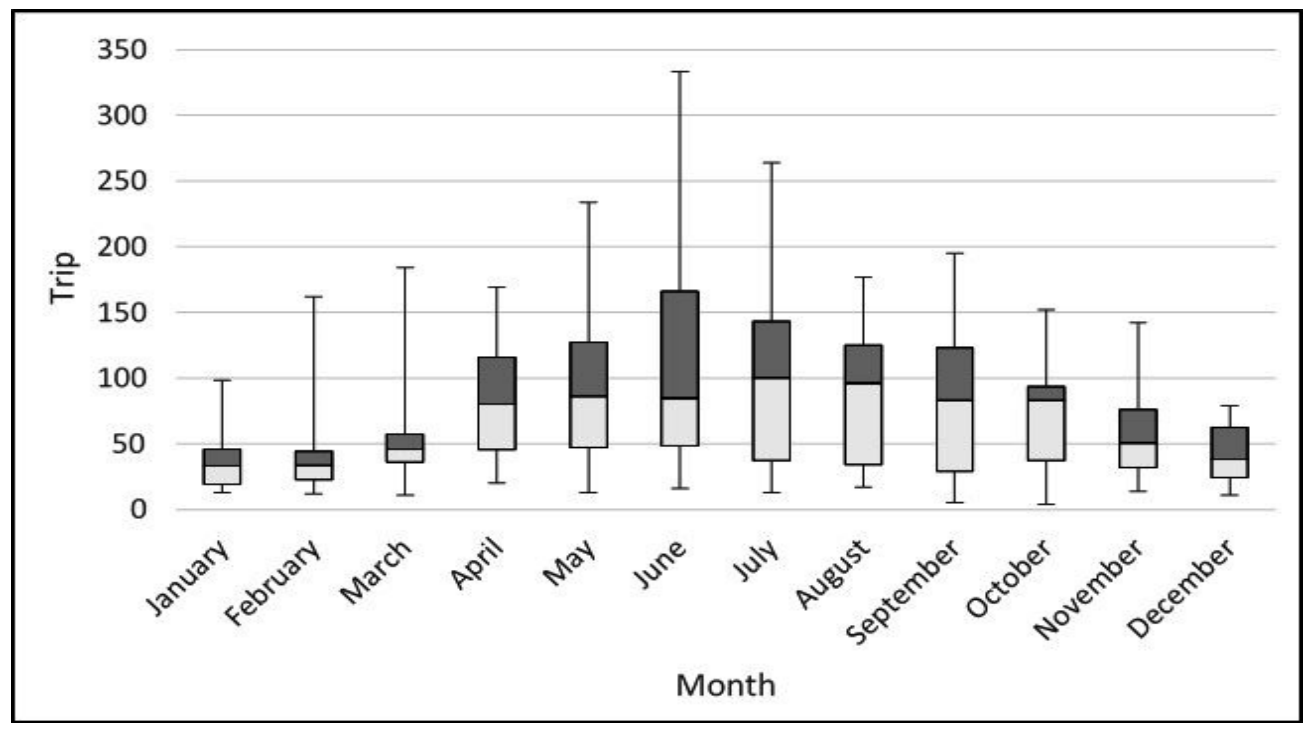

Figure 2. The summated monthly trip data were showing the range of variability within each month over the years 2005-2018. The band inside each bar represents the median, and the middlebox represents the inter quartile range, while the lines outside the box ("whiskers") describe the lower and upper quartiles. 


\section{Monthly Catch-Per-Trip (CPT) 2005-2018}

The average annual CPT of trolling lines fishery from 2005 to 2018 at around $740.33 \mathrm{~kg} /$ trip. The maximum was $1567.19 \mathrm{~kg} /$ trip in February 2006, while the lowest rate of $174.10 \mathrm{~kg} /$ trip occurred in August 2010. The trend analysis of CPT from 2005 to 2018 shows there are two peaks indicate the status of trolling lines fishery (Figure 3).

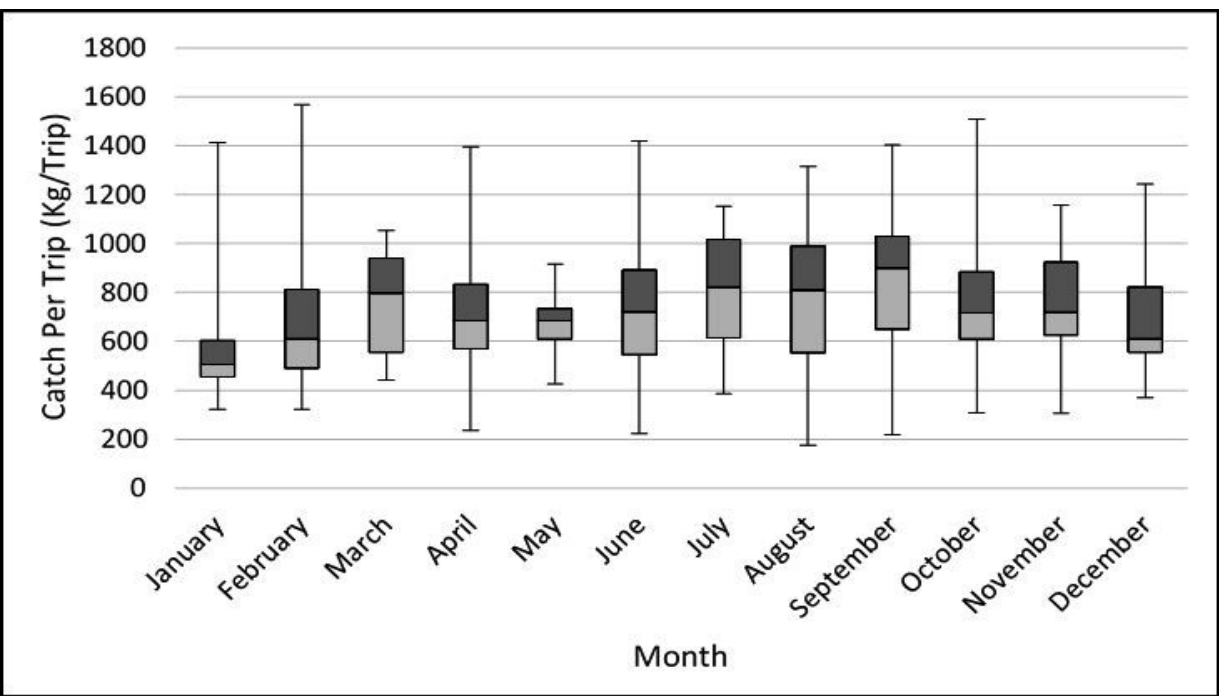

Figure 3. The summated monthly catch-per-trip data were showing the range of variability within each month over the years 2005-2018. The band inside each bar represents the median, and the middlebox represents the interquartile range, while the lines outside the box ("whiskers") describe the lower and upper quartiles.

The CPT value of trolling lines ranges between 461.03 and $1,318.04 \mathrm{~kg}$ per trip. The value of CPT for trolling lines in $2005-2006$ increased $11 \%$ then in 2006 - 2010 with an average decrease of $20.4 \%$. In 2010 - 2012, the value of CPT increased an average of $30.5 \%$, then in $2012-2014$ the value of CPT decreased an average of $17.5 \%$. In $2014-2016$, the value of CPT increased with an average of $62 \%$ and decreased again in 2017 of $38 \%$. In 2017 - 2018, the value of CPT increased 16\% (Figure 4).

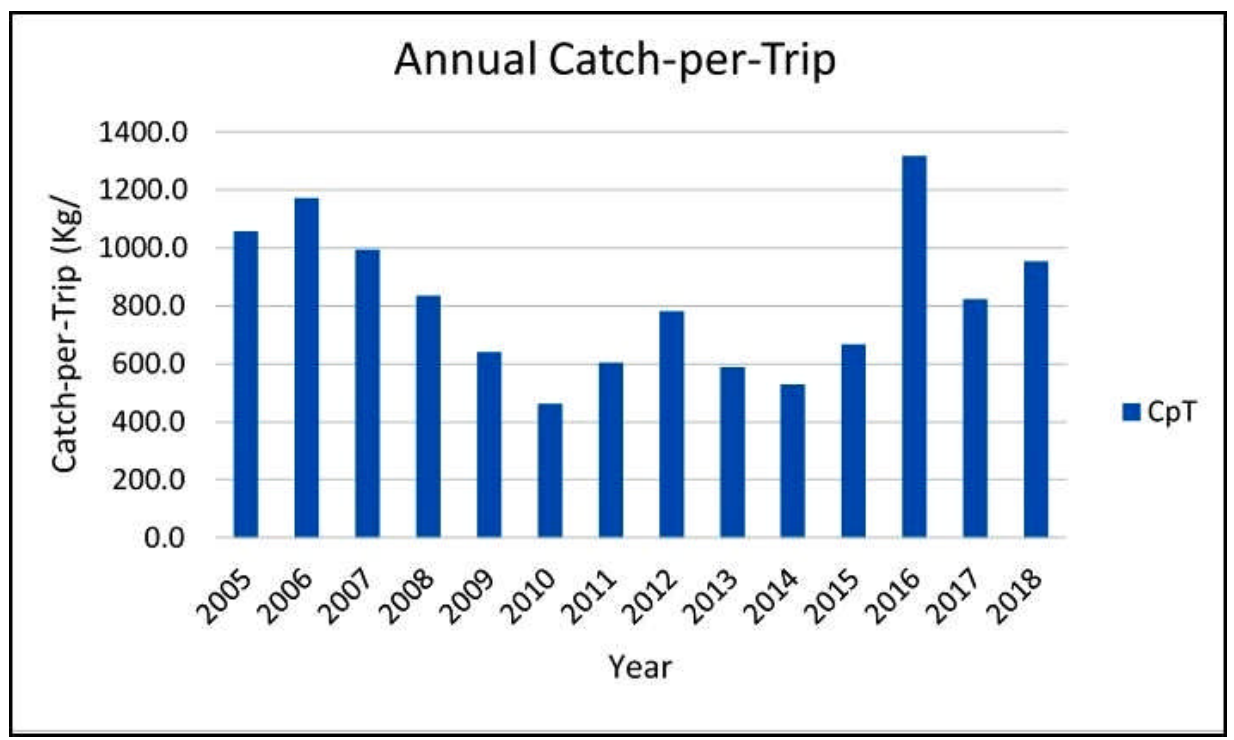

Figure 4. The average annual catch-per-trip (CPT) 2005-2018. 


\section{Discussion}

Catch-per-trip (CPT) data for trolling lines show fluctuations based on monthly data during 14 years (Figure 3.). The monthly data collection for 14 years aims to find out the fishing season for trolling lines fishing during that time period (2005 - 2018). Based on the monthly CPUE graph in 2005 - 2018, the value of CPUE has fluctuated every year. In June, it was the lowest CPUE with a value of $567 \mathrm{~kg} /$ trip while in September it was the highest CPUE with a value of $806 \mathrm{~kg} /$ trip. Overall, in September - October (east season), CPUE values were quite high, ranging from $780-806 \mathrm{~kg} /$ trip. In general, the distribution of catch data is not symmetrical. This is shown because the median value is not in the middle of the box and the top whisker is longer than the bottom whisker. Based on the picture also shows there are no extreme values in CPT data.

The trolling catch rate used in the form of catch data and monthly trips in 2005 - 2018 is then presented in graphical form (Figure 4). In 2012 - 2018, the graph shows an increase in the catches rates trend. The increasing trend in the rate of trolling can be used as an indication that trolling fishing in that year is at a developing stage. Trend that shows the stages of development should be carried out management of fish resources through trolling lines fishing gear. Management is carried out so that sustainable fish resources are created with no overexploitation and the catch rate will continue to increase. Management that can be done through trolling fishing gear are reduction of fishing gear, ship departure arrangements, and regulations for catching fish that are not yet mature gonads or fish that have not spawned in their lives.

Over exploitation is also indicated by the further fishing ground than ones before 2010 that causes it to take more time to get to the fishing ground. Fishing grounds that are further away caused the spread of FADs is also getting farther. The fishing ground factor and the distribution of FADs are related to the fishing trip duration, which was previously 4-7 days became 7-15 days at the sea; therefore, the frequency of fishermen to go fishing in one month also decreases. The structure of the fishing fleet from the beginning until now has not changed even though the trolling line fishermen in the Palabuhanratu Bay only rely on GPS to catch fish.

Based on the graphs obtained, the rate of trolling lines fishing has fluctuated for each month and year. Factors that can influence the value of CPT are total catch and trips. The CPT value increases along with the decreased trips even though the production of fish is constant, and vice versa. Moreover, when the production of fish increases and the trips decrease, the value of CPT will increase. In contrast, when the abundance of fish decreases, the value of CPT will decrease even though the total trips are constant.

The graphic pattern in Figure 4 shows the fluctuation in the catch rate. The CPT trends could be explained by the fact that CPT spatial variations were caused by many conditions, such as water current, water transparency, and fishing pressure (Kantoussan, 2007). The CTC value could be influenced by professional fishing techniques and the ability of fishing gear to catch fish (Coulibaly et al., 2018; Lae, 1982). Low CPT can be caused by the fish in the water column to look for food or to spawn and gather in the waters making fish not vulnerable to fishing activities so that the CPT has decreased (Kantoussan, 2007; Tah et al., 2010). The CPT may also be affected by the differences in catchability among different fishing vessels, gears, and methods, which might confound the indexes of total catch (Richards et al., 1990). In the context of gear power (effective net area), simple linear regression could detect no effect on the CPT. Consequently, although there was a tendency for more experienced fishermen to use greater gear power, this is unlikely to be the cause of the higher CPT achieved by the more experienced fishermen (Boyce et al., 1989).

The value of the catch rates had decreased by $5 \%$, indicating that the level of trolling lines fishing exploitation has decreased in $2005-2012$. The decrease of the $c$ atch trends could indicate that the trolling lines fishery is in a fully exploited status and if it is left unchecked will experience over exploitation or overfishing. This event is in accordance with KEP.45 / MEN / 2011 that large pelagic fish found in Fishery Management Area (FMA) 573, which includes Palabuhanratu Bay, are in fully exploited status. The status is due to the high trip by trolling lines so that the resources of large pelagic fish are decreasing in the region. The graph shows that in 2012 - 2018 the catch rate trend had increased by $7 \%$, which can be used as an indication that trolling lines fishing in that period wa $s$ at a developing stage. The trend that shows the stages of development must be carried out management of fish resources through trolling fishing gear.

\section{CONCLUSIONS}

The value of CPT for 14 years (2005 - 2018) in the Port of Palabuhanratu showed fluctuated trendlines, in one period decreased while in the other period 
increased. The increase and decrease in CPT value are influenced by trips and total catch.

\section{ACKNOWLEDGEMENTS}

Thanks to the Faculty of Fisheries and Marine Sciences, Padjadjaran University, Bandung, Indonesia.

\section{REFERENCES}

Boyce, S. I., Hunte, W., \& Mahon, R. (1989). Sources of variability in catch per trip for the flying fish, Hirundichthys affinis, fishery in Barbados.

Coulibaly, B., Tah, L., Aboua, B., Joanny, T., Koné, T., \& Kouamélan, E. P. (2018). Assessment of fishing effort, catch per unit effort and fish production of the tropical coastal lagoon of grandlahou (Côte-d'ivoire, West Africa). 206 International Journal of Fisheries and Aquatic Studies.

Food and Agriculture Organisation of the United Nations. (1980). The collection of catch and effort statistics. FAO Fisheries Circular.

Food and Agriculture Organisation of the United Nations. (2001). Fishing Gear Types Trolling Lines. Technology Fact Sheet. FAO Fisheries and Agriculture Depart ment. http://www.fao.org/ fishery/

Garrod, D. (1964). Effective fishing effort and the catchability coefficient. In Rapport et procès verbaux des réunions du Conseil International pour I'Exploration de la Mer. 155(14).

Gulland, J. A. (1964). Catch Per Unit Effort as a Measure of Abundance.

Hartini, Imas, \& Firmansyah. (2013). Direction of Coastal Natural Resources Management in Palabuhanratu Bay, Sukabumi Regency. Pasundan University, Bandung.

Inizianti, R. L. (2010). Spatial Analysis of Psp01 Vessel Tuna Catching Area in the South Waters of West Java. Bogor Agricultural Institute.

Kantoussan, J. (2007). Impact de la pression de pêche sur $L$ 'organisation des peuplements de poissons/; Aplication aux reteneus artificielles de Selingue et de Manantali, Mali Afrique de l'Quest. (p. 195). Agrocampus Rennes.
Khan, A. M. A., Gray, T. S., Mill, A. C., \& Polunin, N. V. C. (2018). Impact of a fishing moratorium on a tuna pole-and-line fishery in eastern Indonesia. Marine Policy. https://doi.org/10.1016/ j.marpol.2018.05.014

Khan, A. M. A., Nasution, A. M., Purba, N. P., Rizal, A., Zahidah, Hamdani, H., Dewanti, L. P., Junianto, Nurruhwati, I., Sahidin, A., Supriyadi, D., Herawati, H., Apriliani, I. M., Ridwan, M., Gray, T. S., Jiang, M., Arief, H., Mill, A. C., \& Polunin, N. V. C. (2020). Oceanographic characteristics at fish aggregating device sites for tuna pole-and-line fishery in eastern Indonesia. Fisheries Research. https://doi.org/ 10.1016/j.fishres.2019.105471

Lae, R. (1982). Premières observations sur la pêche en lagune de Grand-Lahou.

Lima, A., Freitas, C., Abuabara, M., M., P., \& Batista, V. (2000). On the standardization of the fishing effort. Acta Amazonica. 30, 167-169.

Nurhayati, A., \& Purnomo, A. H. (2017). Improving Effectiveness of Refrigerated Fish Hold Technology in The National Logistic System/ : Identify ing Strategy for Its Application in the Field. SENTAV: Marine Technology and Sustainable Development.

Oxenford, H. A. (1999). Biology of the dolphinfish (Coryphaena hippurus) in the western central Atlantic: A review. Scientia Marina. https://doi.org/ 10.3989/scimar.1999.63n3-4303

Paloheimo, J., \& Dickie, L. (1964). Abundance and fishing success. Journal Du Conseil. International Pour L'. Exploration de La Mer, 155(1), 152-163.

Puspito, G. (2009). Fishing rod. Faculty of Fisheries and Marine Sciences Bogor Agricultural University.

Richards, L. J., Schnute, J T., \& Hand, C. M. (1990). A Multivariate Maturity Model with a Comparative Analysis of Three Lingcod (Ophiodon elongatus) Stocks. For personal use only. Can. J. Fish. Aquat. Sci. Downloaded from Www.Nrcresearchpress.Com by UNIVERSITYOF ALASKA.

Ricker, W. (1975). Computation and interpretation of biological statistics of fish populations. In Buletin of the Fisheries. Research Board Canada.

Tah, L., Joanny, T. G., N'Douba, V., Kouassi, J. N., \& Moreau, J. (2010). Preliminary estimates of the 
The Annual Changes of CPT of Trolling Lines Fishery in Palabuhanratu West Java, Indonesia (Aprilia, E., et al.)

population parameters of major fish species in Lake Ayamé i (Bia basin; Côte d'lvoire). Journal of Applied lchthyology. https://doi.org/10.1111/j.14390426.2009.01375.x

Wijaya, H. (2012). Catches of Yellowfin Tuna(Thunnus albacares) by Trolling Lines and Management in Palabuhanratu Fishing Port, Sukabumi. University of Indonesia.
Yahya, M. F., \& Rahmat, E. (2017). Beberapa Jenis Pancing (Handline) Ikan Pelagis Besar yang Digunakan Nelayan di PPI Hamadi (Jayapura). Buletin Teknik Litkayasa Sumber Daya Dan Penangkapan. https://doi.org/10.15578/ btl.15.2.2017.115-119 